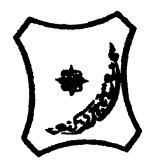

Bayero Journal of Pure and Applied Sciences, 10(2): 25 - 28

Received: April, 2017

Accepted: November, 2017

ISSN $2006-6996$

\title{
A COMPARATIVE ASSESSMENT OF NUTRIENTS AND ANTI-NUTRIENTS CONTENTS OF VARIETIES OF FRIED YAM (Dioscorea SPecie) COMMONLY CONSUMED IN NIGERIA
}

\author{
${ }^{*}$ Abubakar, S. M. and Gana, F. A. \\ Department of Biochemistry, Faculty of Basic Medical Sciences, Bayero University Kano, Nigeria \\ *Correspondence author: smabubakar.bch@buk.edu.ng; +234(0)803 6190005
}

\begin{abstract}
There is limited information on nutrients composition of Nigerian foods. As a result, nutrients intake from Nigerian foods is in most cases estimated using foreign food composition tables. This research determined and compared proximate composition, minerals and anti-nutrients in preboiled fried New and old White Yam (Dioscorea rotundata), Water Yam (Dioscorea alata) and Yellow Yam (Dioscorea cayenensis) purchased at Yankura market, Kano, Northwestern Nigeria. Samples were peeled, boiled and fried. Fried yam samples were analysed for moisture, protein, carbohydrate, fat, ash, fiber and mineral contents using methods of the Association of Official Analytical Chemist. Phytate and cyanide were estimated bytitration. Results were analyzed using ANOVA in GraphPad Instat software. New White Yam exhibited significantly $(P<0.05)$ higher content in moisture $(52.5 \pm 8.40 \mathrm{~g} / 100 \mathrm{~g})$, fiber $(2.0 \pm 0.02 \mathrm{~g} / 100 \mathrm{~g})$, calcium $(13.7 \pm 0.5$ $\mathrm{mg} / 100 \mathrm{~g}) ;$ lower concentration of phytate $(11.3 \pm 0.08 \mathrm{mg} / \mathrm{kg})$ and moderate concentrations of other parameters studied. Water yam contains significantly $(P<0.05)$ higher protein $(5.77 \pm 0.2$ $\%)$, potassium (683 $\pm 3.6 \mathrm{mg} / 100 \mathrm{~g})$ and moderate amount of other parameters studied. Yellow Yam contains significant/y $(P<0.05)$ higher magnesium $(16.3 \pm 1.52 \mathrm{mg} / 100 \mathrm{~g})$, phytate $(31.2 \pm$ $0.40 \mathrm{mg})$, lower fiber $(0.9 \pm 0.03 \mathrm{~g} / 100 \mathrm{~g})$ and moderate amount of other parameters. Old White Yam contains significantly $(P<0.05)$ higher carbohydrate $(37.47 \pm 0.5 \mathrm{~g} / 100 \mathrm{~g})$, lower cyanide $(3.2$ $\pm 0.15 \mathrm{mg} / \mathrm{kg}$ ) and moderate amount of other parameters studied. The fried yam samples studied have variable amount of nutrients and anti-nutrients. Apart from being excellent energy sources, all yam samples studied could contribute to intake of micronutrients.
\end{abstract}

Key words: Fried yam, proximate content, micronutrients, anti-nutrients

\section{INTRODUCTION}

Starchy foods are important part of human diet and may contain essential nutrients required in the body. Yam is one of the staple foods in Nigeria and othertropical African countries with Nigeria as the largest producer. Yam is a member of the genus Dioscorea whichis the largest genus of the family Dioscoreaceae, containing between three and six hundred species (Vernier et al., 1998). Only a few members of the family Dioscoreaceae are cultivated as food crops. In West Africa, a major proportion of yam is consume as boiled, roasted, fried or pounded. Yam is also consumed as "Amala" which is stiff glutinous dough. There is no doubt that yam tubers contribute to the daily calorie and other nutrients need of Nigerians.

There is also lack of local data on the nutritive value of most yam meals and nutritionists are left with the option of relying on foreign data in estimation of nutrient intakes related to yam consumption. Most of the available foods composition tables (Food Standards Agency, 2002), including the West African Food Composition Table (Stadlmayr et al., 2012) did not report composition of fried yams. The objective of this study was to determine and compare the nutrient and anti-nutrient composition of different fried yam samples ( $D$. rotundata, $D$. alata, and $D$. cayenensis.) commonly consume in Nigeria and other African countries.

\section{MATERIALS AND METHODS}

Collection and Preparation of Samples

Yam tubers were purchased at Yankura market, Kano - Nigeria in August, 2015. The tubers were identified at the Department of Plant Biology, Bayero University Kano. Sample specimen numbers BUKHAN 0467, BUKHAN 0519 and BUKHAN 0520for white, yellow and water yams respectively were kept at the Herbarium, Department of Plant Biology, Bayero University Kano. Yam tuber samples were peeled, sliced into small pieces and washed under running water. Each sample $(500 \mathrm{~g})$ was boiled separately in distilled water for 25 minutes using a stainless steel pot at $100^{\circ} \mathrm{C}$ into which one teaspoon of salt was added. The boiled samples were then deep - fried in vegetable oil for 15 minutes after which the samples were allowed to cool and weighed. The fried yam samples were used for proximate and minerals analyses.

Determination of Proximate Composition

Proximate nutrient composition of the yam samples was determined using the standard methods of analysis of Association of Official Analytical Chemists (AOAC, 2004). Moisture content of the samples was determined by an automatic moisture analyzer at $115^{\circ} \mathrm{C}$. The crude protein of the samples was determined using micro-Kjeldahl method. Crude lipid was determined by Soxhlet extraction method using petroleum ether as extracting solvent, while the ash content was determined using a muffle furnace set at $550^{\circ} \mathrm{C}$ for $4 \mathrm{~h}$. 
Carbohydrate was determined spectrophotometrically by Anthrone method and Crude fibre was determined as described by AOAC (2004). All analyses were carried out in triplicates.

\section{Determination of Minerals}

Minerals in the samples were analyzed from solution obtained when $5 \mathrm{~g}$ of the ash sample was digested with $10 \mathrm{ml}$ of $5 \mathrm{~N}$ hydrochloric acid. Iron (Fe), Calcium (Ca), and Magnesium (Mg)content of samples were determined by atomic absorption spectrometry and Potassium (K) was determined by flame photometry according to the methods of AOAC (2004).

\section{Determination of Anti-nutrients}

Phytate in each sample was determined by titration. Each sample $(4 \mathrm{~g})$ was soaked in $100 \mathrm{ml}$ of $2 \%$ hydrochloric acid $(\mathrm{HCl})$ for $5 \mathrm{hrs}$ and filtered. To $25 \mathrm{ml}$ of the filtrate in a conical flask, $5 \mathrm{ml}$ of $0.3 \%$ ammonium thiocyanate solution was added. The mixture was titrated with standard solution of iron(III)chloride $\left(\mathrm{FeCl}_{3}\right)$ as described by Lucas and Markakas (1975).

The level of cyanide in fried yam samples was determined by alkaline filtration method (AOAC, 1984). Sample $(10 \mathrm{~g})$ was dispersed into $200 \mathrm{ml}$ distilled water and $10 \mathrm{ml}$ of orthophosphoric acid was added. The mixture was mixed and left to stand for 12 hours to release the bound hydrogen cyanide. A drop of tannic acid as an antifoaming agent was added. To $20 \mathrm{ml}$ of the distillate $40 \mathrm{ml}$ of distilled water was added followed by the addition of $8 \mathrm{ml}$ of $0.06 \mathrm{~N}$ sodium hydroxide $(\mathrm{NaOH})$ and $2 \mathrm{ml}$ of $0.05 \mathrm{~N}$ potassium iodide (KI). The mixture was titrated with $0.02 \mathrm{~N}$ silver nitrate $\left(\mathrm{AgNO}_{3}\right)$ solution until a faint turbidity was obtained. Each $1 \mathrm{ml}$ of $0.02 \mathrm{~N} \mathrm{AgNO}_{3}$ is equivalent to $1.8 \mathrm{mg}$ of cyanide.

\section{Statistical Analysis}

Analysis of variance (ANOVA) was usedin results analysis. Statistical significance was considered at $\mathrm{p}<0.05$.

\section{RESULTS}

Results of proximate, minerals and anti-nutrients content of the fried yam samples studied are shown in Tables 1, 2 and 3 respectively. Moisture, fat and ash content showed no significant difference $(p>0.05)$ among all four samples. However, significant difference was recorded $(p<0.05)$ when means of protein, carbohydrate and fiber content were compared. Water yam have significantly $(p<0.05)$ higher protein content compared to other samples studied. Carbohydrate content significantly $(p<0.05)$ differed between samples with highest amount observed in old white yam. New white and water yams showed significantly $(p<0.05)$ higher fiber content than both yellow and old white yams.

Concentration of iron in the fried yam samples was not significantly different $(p>0.05)$. However, calcium, potassium and magnesium concentrations differed significantly $(p<0.05)$ between samples with new white, water and yellow yams respectively higher in calcium, potassium and magnesium.

There was significant $(p<0.05)$ variation in the phytate and cyanide content among the fried yam samples studied. The highest cyanide and phytate contents were respectively in new white and yellow yams.

\section{DISCUSSION}

According to the Nigerian Food Composition Table (Sanusi et al., 2017), raw white, yellow and water yams have respective proximate content (in $\mathrm{g} / 100 \mathrm{~g}$ ) of water $(61.43 ; 70.31 ; 65.50)$, protein $(2.00 ; 2.25$; $2.40)$, fat $(0.4 ; 0.28 ; 0.10)$, Carbohydrate (31.57; $24.22 ; 26.50)$, fibre $(1.05 ; 2.73 ; 2.50)$ and ash (1.23; $1.58 ; 1.40)$. Protein content of pre-boiled fried yam samples studied ranged from $4.97-5.77 \mathrm{~g} / 100 \mathrm{~g}$. Surprisingly, the findings of Nduka et al. (2016) reported very low protein content of 0.00413 to $0.00525 \mathrm{~g} / 100 \mathrm{~g}$ in raw $D$. rotundata yam tubers. This is unexpected of a raw yam tubers and may possibly be due to conversion errors as the authors showed protein calculated in percentage but presented it as $\mathrm{mg} / 100 \mathrm{~g}$ in the results table. On the other hand, the protein contents obtained in this study is less than the protein content $(7.10-9.12 \mathrm{~g} / 100 \mathrm{~g})$ reported in boiled $D$. rotundata in previous study (Ezeocha and Ojimelukwe, 2012) suggesting the advantage of boiling over frying on the protein content of yam. It is worthy of note that in northern Nigeria, most people fry yam with egg and this may compliment the protein loss due to frying. Adepoju (2012) reported a protein content of $9.7 \mathrm{~g} / 100 \mathrm{~g}$ in yam (D. rotundata) porridge but that fried yam has $3 \%$ protein. The protein content reported in fried yam is less than the amount found in the present study. This could be due difference in processing method as Adepoju (2012) did not pre-boil before frying. The higher protein content in the yam porridge reported by Adepoju (2012) could be due to contribution of protein from other ingredients used. Other related studies (Marfo et al., 1990; Udensi, et al., 2010; Udensi, et al., 2008; Lawal et al., 2012; Chandrasekara and Kumar, 2016; Bradbury et al., 1988; Shajeela et al., 2011; Polycarp et al., 2012) reported variable amounts of protein in yam and yam - based meals. These variations related to processing or cooking methods underscore the importance of developing a detailed country and regional food composition tables to enable more accurate estimates of nutrient intake of the consumers. This is necessary to guide nutrition policy making and advice. The high mean fat content of fried yam $(5.07$ to $7.00 \mathrm{~g} / 100 \mathrm{~g})$ found in this study is in agreement with the finding of Adepoju (2012) who reported $5.3 \mathrm{~g} / 100 \mathrm{~g}$ crude lipid in fried yam ( $D$. rotundata). According to Lawal et al. (2012), fried yam with stew have mean fat content of 12.72 $\mathrm{g} / 100 \mathrm{~g}$. The fat content in fried yams or fried yam with stew could be largely contributed from the vegetable oil and ingredients used in frying or stew making. The fat will contribute to overall gross energy of the fried yam meal. Ezeocha and Ojumelukwe, (2012) reported the presence of $1.15 \mathrm{~g} / 100 \mathrm{~g}$ in raw and less than $1 \mathrm{~g} / 100 \mathrm{~g}$ lipids in boiled yam samples. Nduka et al. (2016), Marfo (1990), Lawal et al. (2012) and Polycarp et al. (2012) observed less than 1 $\mathrm{g} / 100 \mathrm{~g}$ fat content in raw yam samples. This further suggest the need for a comprehensive food table with details of yam variety types and processing methods. 
The content of carbohydrate $(31-37 \mathrm{~g} / 100 \mathrm{~g})$ found in fried yams studied is in close agreement with Marfo et al. (1990) who found carbohydrate content of 36.5 $\mathrm{g} / 100 \mathrm{~g}$ and $38.30 \mathrm{~g} / 100 \mathrm{~g}$ in raw yam and cocoyam respectively. On the other hand, Polycarp et al. (2012) reported that carbohydrate in different yam varieties range from 77.5 to $87.3 \mathrm{~g} / 100 \mathrm{~g}$. However, the carbohydrate content in fried yams in this study were lower than the reported carbohydrate content (53.8 $\mathrm{g} / 100 \mathrm{~g}$ ) obtained in fried yam (Adepoju, 2012) previously. The lower carbohydrate content in this study could be due to pre-boiling of samples prior to frying.

It is worthy of note that Adepoju (2012) obtained variable amounts of carbohydrate (from $20 \mathrm{~g} / 100 \mathrm{~g}$ in hot water pounded yam to $60.6 \mathrm{~g} / 100 \mathrm{gamala}$, a thick yam powder paste) depending on the processing methods. It is obvious that differences in yam samples and processing methods play significant role in determining nutrient content of various yam based meals commonly consume in Nigeria and other African countries.

The low fibre content in fried yam samples (0.9 - 2.0 $\mathrm{g} / 100 \mathrm{~g}$ ) concur with previous findings of $1.2 \mathrm{~g} / 100 \mathrm{~g}$ in fried yam (Adepoju, 2012). Other studies showed fibre content of between $0.39 \mathrm{~g} / 100 \mathrm{~g}$ and $7.69 \%$ in yams processed in various ways ranging from raw, boiled, pounded, porridge, etc. (Lawal et al., 2012; Marfo et al., 1990; Udensi et al., 2008 and 2010; Ezeocha and Ojumelukwe, 2012; Polycarp et al., 2012; Adepoju, 2012; Shajeela et al., 2011). These results suggest the effect of processing methods on fibre content of yam. Dietary fibre consumption has been associated with decreased risk of chronic diseases development (Lockyer et al., 2016).

Dietary minerals are known to play various roles (transport across biological membrane, signal transduction through creation of membrane potentials, enzyme cofactors, relaxation and contraction of muscles, etc.) in ensuring normal running of physiological processes of the body. The calcium, potassium, magnesium and iron contents in fried yam studied suggest its potential as a contributor to the daily/adequate intake of these minerals among habitual yam consumers. The variations observed in the amount of calcium ( 9 to $13.7 \mathrm{mg} / 100 \mathrm{~g}$ ), potassium (383 to $683 \mathrm{mg} / 100 \mathrm{~g}$ ), iron ( 0.3 to $0.5 \mathrm{mg} / 100 \mathrm{~g}$ ) and magnesium (11.3 to $16.3 \mathrm{mg} / 100 \mathrm{~g}$ ) among the fried yam samples studied could be as a result of possible differences in varieties of yams studied as well as their cultivation conditions. Previous studies (Chandrasekara and Kumar, 2016; Hailu and Addis, 2016; Adepoju, 2012; Udensi et al. 2008 and 2010; Shajeela et al. 2011; Akin-Idowu et al. 2009) have shown similar trends of variation in minerals content of raw and processed yam varieties. For example, Polycarp et al. (2012) have reported calcium content of 6.5 to $116.5 \mathrm{mg} / 100 \mathrm{~g}$, potassium content of 475 to $1475 \mathrm{mg} / 100 \mathrm{~g}$, iron content of 1.5 to $9 \mathrm{mg} / 100 \mathrm{~g}$ and magnesium content of 35.5 to 83.5 $\mathrm{mg} / 100 \mathrm{~g}$. These data further supported the need for a comprehensive yam and yam-based foods composition to ease nutrient intake assessment in areas where yam is one of the frequent foods consumed.

Anti-nutrients in foods are known to inhibit proper absorption and utilization of essential nutrients thereby decreasing bioavailability. Phytate content of fried yam studied is lower than the previously reported in different varieties of yam (Polycarp et al., 2012). Phytate content of yam was found to be significantly reduced in boiled and pounded yam (Akin-Idowu et al., 2009). The cyanide content (3.2 to $7.2 \mathrm{mg} / \mathrm{kg}$ ) in fried yam samples studied is less than the previously (Udensi et al., 2010) reported cyanide content of 9.62 to $12 \mathrm{mg} / \mathrm{kg}$ in different varieties of yam. Collectively, these findings have shown variation in cyanide and phytate contents of yam possibly due to variety differences and processing methods. Frying is relatively associated with lower phytate and cyanide content.

Table 1: Proximate Composition(g/100g) of Yam Tuber Samples Studied

\begin{tabular}{lllllll}
\hline Sample & Protein & Fat & Ash & Moisture & Carbohydrate & Fibre \\
\hline NWY & $4.97 \pm 0.1^{\mathrm{a}}$ & $7.00 \pm 0.3^{\mathrm{a}}$ & $2.45 \pm 1.13^{\mathrm{a}}$ & $52.5 \pm 8.40^{\mathrm{a}}$ & $31.20 \pm 0.1^{\mathrm{a}}$ & $2.0 \pm 0.02^{\mathrm{a}}$ \\
OWY & $5.03 \pm 0.1^{\mathrm{s}}$ & $5.22 \pm 0.5^{\mathrm{a}}$ & $3.22 \pm 0.23^{\mathrm{a}}$ & $47.1 \pm 0.70^{\mathrm{a}}$ & $37.47 \pm 0.5^{\mathrm{d}}$ & $1.92 \pm 0.02^{\mathrm{b}}$ \\
WY & $5.77 \pm 0.2^{\mathrm{b}}$ & $7.67 \pm 2.0^{\mathrm{a}}$ & $2.53 \pm 0.23^{\mathrm{a}}$ & $49.2 \pm 1.36^{\mathrm{a}}$ & $33.17 \pm 1.5^{\mathrm{b}}$ & $1.96 \pm 0.03^{\mathrm{a}}$ \\
YY & $5.13 \pm 0.4^{\mathrm{a}}$ & $5.07 \pm 0.1^{\mathrm{a}}$ & $2.33 \pm 0.12^{\mathrm{a}}$ & $51.0 \pm 1.00^{\mathrm{a}}$ & $35.7 \pm 0.4^{\mathrm{c}}$ & $0.90 \pm 0.03^{\mathrm{b}}$ \\
\hline
\end{tabular}

Results are presented as mean \pm standard deviation of triplicate determinations. Values with different superscripts on the same column are significantly different $(P<0.05)$.New white yam $(N W Y)$, old white yam $(\mathrm{OWH})$, water yam (WY) and yellow yam (YY).

Table 2: Calcium, Potassium, Iron and Magnesium Content (mg/100g) of Yam Tuber Samples Studied

\begin{tabular}{lllll}
\hline Sample & Calcium & Potassium & Iron & Magnesium \\
\hline NWY & $13.7 \pm 0.5^{\mathrm{a}}$ & $383 \pm 3.6^{\mathrm{a}}$ & $0.4 \pm 0.05^{\mathrm{a}}$ & $11.3 \pm 1.15^{\mathrm{a}}$ \\
OWY & $9.0 \pm 1.7^{\mathrm{b}}$ & $493 \pm 11.5^{\mathrm{b}}$ & $0.3 \pm 0.05^{\mathrm{a}}$ & $11.7 \pm 2.08^{\mathrm{c}}$ \\
WY & $11.7 \pm 0.5^{\mathrm{c}}$ & $683 \pm 3.6^{\mathrm{c}}$ & $0.5 \pm 0.39^{\mathrm{a}}$ & $14.1 \pm 2.08^{\mathrm{a}}$ \\
YY & $10.3 \pm 1.5^{\mathrm{d}}$ & $507 \pm 30.5^{\mathrm{d}}$ & $0.5 \pm 0.2^{\mathrm{a}}$ & $16.3 \pm 1.52^{\mathrm{b}}$
\end{tabular}

Results are presented as mean \pm standard deviation of triplicate determinations. Values with different superscripts on the same column are significantly different $(P<0.05)$. New white yam $(N W Y)$, old white yam $(\mathrm{OWH})$, water yam (WY) and yellow yam (YY). 
Bajopas Volume 10 Number 2 December, 2017

Table 3: Phytate and Cyanide Content $(\mathrm{mg} / \mathrm{kg})$ of Yam Tuber Samples Studied

\begin{tabular}{lll}
\hline Sample & Phytate & Cyanide \\
\hline NWY & $11.3 \pm 0.08^{\mathrm{a}}$ & $7.2 \pm 0.15^{\mathrm{a}}$ \\
OWY & $11.8 \pm 0.04^{\mathrm{d}}$ & $3.2 \pm 0.15^{\mathrm{d}}$ \\
WY & $13.9 \pm 0.05^{\mathrm{b}}$ & $3.5 \pm 0.11^{\mathrm{b}}$ \\
YY & $31.2 \pm 0.40^{\mathrm{c}}$ & $4.5 \pm 0.06^{\mathrm{c}}$
\end{tabular}

Results are presented as mean \pm standard deviation of triplicate determinations. Values with different superscripts on the same column are significantly different $(P<0.05)$. New white yam $(N W Y)$, old white yam $(\mathrm{OWH})$, water yam (WY) and yellow yam (YY).

\section{CONCLUSION}

Results of this study suggests that the proximate composition of fried white, yellow and water yams studied varies slightly. However, the fried yams studied appear to be potential contributors of calories and essential minerals to the daily requirements of habitual consumers.

\section{REFERENCES}

Adepoju O.T. (2012): Effect of processing methods on nutrient retention and contribution of white yam (Dioscorea rotundata) products to nutritional intake of Nigerians. African Journal of Food Science. 6(6): 163-167

Akin-Idowu P. E., Asiedu R., Maziya-Dixon B., Odunola A., and Uwaifo A. (2009): Effects of two processing methods on some nutrients andanti-nutritional factors in yellow yam (Dioscorea cayenensis). African Journal of Food Science. 3(1):022-025.

AOAC(2004): Official Methods of Analysis. Associationof Official Analytical Chemists International Washington, DC, USA.

AOAC(1984): Official Methods of Analysis. Association of Official Analytical Chemists International Washington, DC, USA

Bradbury, J. H., Bradshow, K., Jealous, W., Holloway, W. and Phimpisane, T. (1988): Effect of cooking on nutrient content of tropical root crops from the South Pacific. J. Sci. Agric. 43: 333 - 342.

Chandrasekara, A. and Kumar, T. J. (2016): Roots and tuber crops as functional foods: a review on phytochemical constituents and their potential health benefits. International Journal of Food Science. 2016: 1 - 15.

Ezeocha V.C. and Ojimelukwe P.C. (2012): The impact of cooking on the proximate composition and antinutritional factors of water yam (Dioscorea alata). Journal of Stored Products and Post-Harvest Research. 3(13). 172-176.

Food Standards Agency (2002): McCance and Widdowson's The Composition of Foods. Sixth Summary Edition. Royal Society of Chemistry. Cambridge. 537pp.

Hailu, A. A. and Addis, G. (2016): The content and bioavailability of mineral nutrients of selected wild and traditional edible plants as affected by household preparation methods practiced by local community in Benishangul Gumuz Regional State, Ethiopia. International Journal of Food Science. 2016: 1 - 7 .

Lawal, O. O., Agiang, M. A. and Eteng, M. U. (2012): Proximate and anti-nutrient composition of white Guinea yam (Dioscorea rotundata) diets consumed in Ibarapa, South West region of Nigeria. J. Nat. Prod. Plant Resour. 2 (2):256-260

Lockyer, S., Spiro, A. and Stanner, S. (2016). Dietary fibre and the prevention of chronic disease - should health professionals be doing more to raise awareness? Nutrition Bulletin. 41: 214 - 231.

\section{Authors' Contributions}

S. M. Abubakar designed and supervised the conduct of the study. F. A. Gana conducted sampling, carried laboratory and statistical analyses. F. A. Gana drafted the manuscript. Both authors read, corrected and approved the final manuscript.

Conflict of Interest: No conflict of interest to declare.

Lucas, G. M. and Markakas, P. (1975). Phytic acid and other phosphorus compounds of bean (Phaseolus vulgeris). J. Agric. Ed. Chem., 23:13-15.

Marfo, E. K., Simpson, B. K., Idowu, J. S. and Oke, O. L. (1990): Effect of local food processing on phytate levels in cassava, cocoyam, yam, maize, sorghum, rice, cowpea, and soybean.J. Agric. Food Chem. 38: 1580 1585.

Nduka, A. D., Jubilant, U. O., and Alozie, A. (2016): Effect of Leaf Powder Treatment on Root-Knot Nematode (Meloidogyne incognita) and Proximate Composition of Yam Tubers; Implication on Food Security. J Plant SCi Res. 3(1): 144.

Polycarp, D., Afoakwa, E. O., Budu, A. S. and Otoo, E. (2012): Characterization of chemical composition and anti-nutritional factors in seven species within the Ghanaian yam (Dioscorea) germplasm. International Food Research Journal 19 (3): 985-992.

Sanusi, R. A., Akinyele, I. A., Ene-Obong, H. N. and Enujiugha, V. (2017). Nigerian Food Composition Table Version 1.0 (Harmonised Edition). Straight-Gate Publishers Limited. Pp. 7 - 9.

Shajeela, P. S., Mohan, V. R., Jesudas, L. L. and Soris, P. T. (2011): Nutritional and antinutritional evaluation of wild yam (Dioscorea spp.). Tropical and Subtropical Agroecosystems. 14 (2011): 723-730.

Stadlmayr B., Charrondiere U. R., Enujiugha V. N., Bayili G. R., Fagbohoun G. E., Samb B., Addy P., Barikmo I., Ouattara F., Oshuag A., Akinyele I., Annor G A., Bomfeh K., Ene-Obong H., Smith I. F., Thiam I., Burlingame B. (2012). "West African Food Composition Table'. Food and Agricultural Organizations of The United Nations. Rome. Pp 19-21.

Udensi, E. A., Oselebe, O. A. and Iweala, O. O. (2008): The investigation of chemical composition and functional properties of water yam (Dioscorea alata): Effect of varietal differences. Pakistan Journal of Nutrition. 7 (2): $342-344$.

Udensi, E. A., Oselebe, O. A. and Onuocha, A. U. (2010):Antinutritional assessment of $D$. alata varieties. Pakistan Journal of Nutrition. 9 (2): 179-181.

Vernier P., Berthaud J., Bricas N. and Marchand J. L. (1998). "L'intensificationdes techniques de culture de l'igname. Acquis et contraintes". In: L'igname, planteséculaire et culture d'avenir/Yam, Old Plant and Crop for the Future. Actesdu séminaire international Cirad-Inra-OrstomCoraf, 3-6 Juin 1997,Montpellier, France. Montpellier, France: CIRAD. pp. 93-101. 